\section{Introducing statistical machine translation in translator training: from uses and perceptions to course design, and back again}

\author{
Caroline Rossi
}

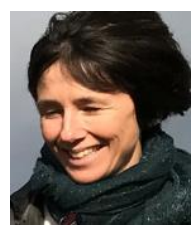

Caroline Rossi caroline.rossi@univgrenoble-alpes.fr Université Grenoble Alpes ORCID: 0000-0003-3231-3610 2016.

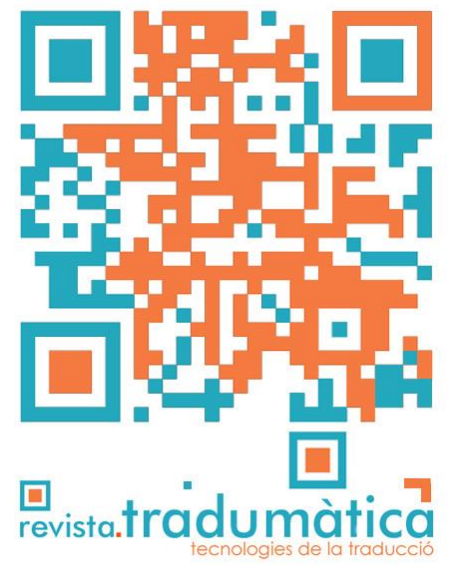

Abstract

While translation technology is now at the core of most translator training programmes, only a handful include teaching of statistical machine translation (SMT). This paper reports on the design and evaluation of an SMT course, which we introduced in the second year of our Master's degree in Multilingual Specialised Translation in

Keywords: Curriculum design; Statistical machine translation (SMT); translator training; technology acceptance model (TAM); self-efficacy; perception survey.

Resum

Tot i que les tecnologies de la traducció actualment son una part essencial dels programes de formació de traductors, només uns quants d'ells incoporen continguts de traducció automàtica estadística (TAE). Aquest article presenta una proposta de disseny $\mathrm{i}$ avaluació d'una assignatura de TAE, que en el nostre cas s'introdueix en el segon curs del programa de Màster en Traducció Especialitzada Multilingüe des de 2016.

Paraules clau: disseny curricular; traducció automàtica estadística (TAE); formació de traductors; model d’acceptació tecnològica (MAT); autoeficàcia; qüestionari sobre percepció.

\section{Resumen}

Aunque las tecnologies de la traducción actualment son una parte essencial de los programes de formación de traductores, únicamente unos cuantos de ellos incorporan contenidos de traducción automàtica estadística (TAE). Este articulo presenta una propuesta de diseño y evaluación de una assignatura de TAE, qne en nuestro caso se introduce durante el segundo curso del programa de Máster en Traducción Especializada Multilingüe desde 2016.

Palabras clave: diseño curricular; traducción automàtica estadística (TAE); formación de traductores; model de aceptación tecnològica (MAT); autoeficàcia; cuestionario sobre perepción. 


\section{Introduction: translators and technologies}

Why teach statistical machine translation (SMT)? Translators generally respond favourably to CAT tools and translation memories (TMs), but they also voice negative feelings about current uses of machine translation (MT) as well as automation at large (Koskinen and Ruokonen, 2017, LeBlanc 2013, 2017). As for language and translation teachers, although they all know about MT, very few actually choose to bring the technology to their classrooms (Niño 2009: 252) in spite of numerous successful attempts reported in the literature over the past three decades (Corness, 1985). Generalised use of MT does correspond to a current trend, which is currently boosted by the success of Neural Machine Translation, but very few non-commercial surveys are available (Cadwell et al. 2016: 225, Gaspari et al. 2015: 335-336, but see Presas et al. 2016 for a study of the current situation in Spain). Besides, if we consider both professionals' and teachers' mixed feelings, contriving the use of MT by merely training students to work with it is not likely to improve practices and perceptions.

The assumption that guided us as we introduced this new class is twofold. First, because of the considerable changes it brings about, we need critical approaches to MT, looking at how translation is constructed, asking whose interests are served by recent developments and what factors help translation technologies succeed (Kenny, 2017: 2-3). Second, and as a result, students also need to be critically aware of current trends and the various reconfigurations they imply (Pym, 2012). So far, the pedagogically inspired literature has been mostly concerned with teaching computeraided translation, with very little focus on MT (Kenny and Doherty, 2014: 277), but ground-breaking work conducted at Dublin City University (DCU) paved the way for the development and sharing of good practice. The teaching of and reflection on MT at DCU began more than a decade ago (Kenny and Way, 2001) and led up to the design of an SMT syllabus for translation students (Doherty and Kenny, 2014). The present paper proposes a more lightweight implementation, based on similar principles, in the hope that it will encourage new initiatives of the same kind and help consolidate critical knowledge. Our main research question is whether the course will retain the potential to enhance self-efficacy and improve our students' perceptions, thus effectively empowering them,

\section{Course design}

While translation technology is now at the core of most translator training programmes (see e.g. EMT Expert Group, 2009) only a handful of those programmes include teaching of statistical machine translation (SMT). We started from Kenny and Doherty's pioneering initiative, as described and analysed in two key papers (Kenny and Doherty, 2014; Doherty and Kenny, 2014) to design an SMT course which we introduced in the second year of our Master's degree in Multilingual Specialised Translation at Grenoble Alps University in 2016.

Translation at Grenoble Alps University in 2016. 


\subsection{Context}

The course was a short but compulsory module for second year Master students, but there were no marked assignments. In 2016, there were 19 students enrolled in the second year of our Master's degree, and ages ranged from 21 to 56 (mean age was 25). The students had all been exposed to translation technologies in the previous year: they had attended a 24-hour introductory module on CAT tools and learnt how to use SDL Trados Studio (2015). They had also completed their first internship and used the tools in that context: 14 students had already used one or various CAT tools in a professional context. Finally, 15 students had already used free MT engines such as Google Translate or Reverso, but only one had used MT within a CAT tool.

We adjusted Kenny and Doherty's proposal to our curriculum and we tried to design a more lightweight course while remaining faithful to their approach. We could not, however, fully develop their "holistic, empowering approach to teaching SMT, one that does not exclude human translators from any part of the process in which they could conceivably participate." (2014: 285). Because our 12-hour course was not long enough to teach students how to train their own SMT system, we used mainly the European Commission's engine (MT@EC), which for the most part is still based on MOSES (Koehn, 2016), and trained on the 1.65-billion-word Translation Memory of the European Commission's Directorate-General for Translation (DGT). We were careful not to introduce MT@EC as a mere tool. Rather, we sought to emphasise that it was a social construction by including numerous depictions of the social context in which it was developed (Bijker, 2009: 88), before explaining how it was built and what its current uses were. In order to convey a vivid picture of DGT translators' use of MT@EC, we used data from existing DGT studies (mainly Koskinen, 2008 and Cadwell et al., 2016) as well as the results of our own 3-week ethnographic case study, conducted within the framework of the European Commission's Visiting lecturer scheme. Because the literature on "translating institutions" is still sparse (Koskinen, 2008) and even more so when it comes to "the human factors pertaining to MT" (Cadwell et al. 2016: 226), first-hand data were a welcome addition: they enabled us to convey a situated picture of the most recent trends. In additions, being Europe's biggest translation service (with more than 1,500 permanent translators, and more than 2 million pages processed both internally and externally) and an institution that strives to promote translation quality and translator's wellbeing (see e.g. DGT's 2016 annual activity report, annex 2), the DGT provided our students with an ideal professional scenario.. Here are two examples of how we depicted the social construction of MT at the DGT. First, we used official figures and graphs (see figure 1 below) for students to understand the economic and social context constraining MT's social role (Olohan, 2017 : 274) 


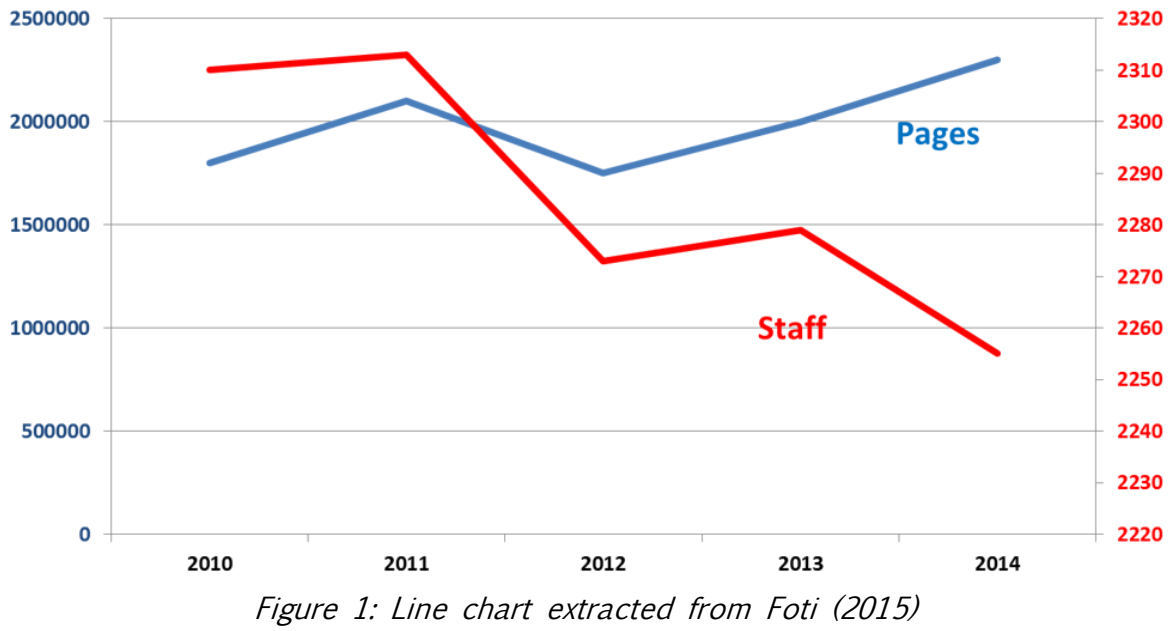

Second, we quoted declarations about the development of language technologies by the European commission, showing that they were the result of major choices, e.g.: "The European Commission has already invested more than $€ 200$ million over the last seven years on research and innovation in language technologies that have the potential to break through language barriers." (Ansip, 2016). This enabled us to explain the need to reach beyond technological determinism (Olohan, 2017 : 265).

\subsection{Strategies}

Throughout the course, we followed two strategies aimed at empowering our students. The first one involved fostering the development of knowledge in two ways: (1) a better understanding of probabilistic (statistical) processing and (2) sound knowledge on recurrent errors, their origins and possible remedies. In explaining statistical processing, we stressed that the data used were nothing more than a compilation of all existing translations made by DGT translators (see Way and Hearne, 2011, on the importance of disseminating such knowledge among translators), and we introduced students to EURAMIS, the European Advanced Multilingual Information System containing the DGT's TM and connecting it to the current translation environment through a metasearch engine called Quest. To explain language models and probabilistic treatment within SMT, we had students compute simple probabilities from a very small corpus, as explained in Kenny and Doherty (2014: 278 et sq; see also Hearne and Way, 2011 for a more in-depth presentation)

As regards the second direction, we did not work with a typology of errors, but we asked students to detect recurrent errors and try to explain them in their own words. This enabled us to emphasise their reliance on the meta-linguistic and meta-cognitive skills that are at the heart of translator training (Lavault-Olléon and Carré, 2012), and we encouraged students to bring conscious strategies to bear on their interactions with MT.

The second strategy involved enhancing necessary skills while "constructing the translator's role in SMT workflows" in the broadest possible way (Kenny and Doherty, 2014: 287). This involved dealing with SMT as thoroughly as we could and introducing 
post-editing (PE) at a later stage. Students used SMT with a variety of short texts and compared MT output with their own translations: they worked individually on the first document, but their second assignment involved cooperation in small groups. We encouraged students to voice their feelings and any issues they may come across. Perceptions were discussed in a focus group session, with exploratory questions about how they conceived the translator's interaction with MT and whether they thought special skills were involved. PE skills were dealt with separately: after the 12-hour module, the students attended two weekly two-hour lab sessions in which they were trained to post-edit MT output within SDL Trados Studio ${ }^{1}$. These sessions were taught by a professional translator, who used a real translation project and fully explained why and how MT had been used.

\section{Assessing students' perceptions}

Paradoxically enough, students with little to no experience of using MT within a professional context have been shown to have sceptical to negative perceptions (Doherty and Moorkens, 2013: 127). Such perceptions do, however, correspond to a frequently reported premature bias that might at least partly disappear as students start interacting with MT and understand how it works.

\subsection{Task-based assessment}

The first evidence we obtained suggested that the limited amount of time students actually spent interacting with MT outputs might have been more likely to reinforce such negative bias. Table 1 below sums up the results of the first series of tasks students did individually: they started with a longer text and only two students translated (using pen and paper only) while the rest of the group worked from two distinct MT outputs, and the next tasks involved both translation and post-edition for the whole group.

\begin{tabular}{|c|c|c|c|c|}
\hline $\begin{array}{c}\text { Average time } \\
\text { spent } \\
\text { translating } \\
\text { (No students) }\end{array}$ & $\begin{array}{c}\text { Average time } \\
\text { spent post- } \\
\text { editing (No } \\
\text { students) }\end{array}$ & $\begin{array}{c}\text { No students } \\
\text { who enjoyed } \\
\text { post-editing }\end{array}$ & $\begin{array}{c}\text { No of } \\
\text { students who } \\
\text { (would have) } \\
\text { preferred } \\
\text { translation }\end{array}$ & $\begin{array}{c}\text { No words } \\
\text { translated (TR) } \\
\text { and/ or post- } \\
\text { edited (PE) }\end{array}$ \\
\hline $\begin{array}{c}39 \text { minutes } \\
(2)\end{array}$ & $\begin{array}{c}21 \text { minutes } \\
(17)\end{array}$ & 4 & 13 & 277 \\
\hline
\end{tabular}

\footnotetext{
${ }^{1}$ The sessions were also aimed at giving students a feel for the current integration of SMT into CAT tools, blurring the boundaries between TMs and MT. Given that our students all receive extensive training with SDL Trados Studio (2015), starting on the first year of their Master's degree, and all use SDL Trados Studio (2015) on a very regular basis, we thought it would be easier for them to focus on the specific requirements of the PE task.
} 


\begin{tabular}{|c|c|c|c|c|}
\hline $7 \min (19)$ & $3.8 \min (19)$ & 5 & 12 & $49 \mathrm{TR} / 52 \mathrm{PE}$ \\
\hline $5.6 \min (19)$ & $2.6 \min (19)$ & 4 & 13 & $41 \mathrm{TR} / 45 \mathrm{PE}$ \\
\hline
\end{tabular}

Table 1. Task duration and student perceptions

Although standard deviation was quite high for all of the above means, the amount of time spent post-editing was always considerably smaller than time spent translating. Students thus noticed that MT did improve their level of productivity, but this did not significantly affect their perceptions, as very few reported that they enjoyed working with a raw MT output.

We did not ask students to keep a record of the time spent on each task while working in small groups, as we thought it might have disturbed interactions. Based on our focus group assessment of perceptions, however, our assumption is that little to no variation would have been found.

\subsection{Overall assessment}

We combined quantitative and qualitative data to achieve a contrastive assessment of students' perceptions. First, we built two complementary 20-question surveys that our 19 students completed before and after the course. The data included different types of scores (see appendix for details) and they were analysed by computing a series of composite indices, which are presented and discussed in what follows. Qualitative analyses of our focus group data were then used to illuminate our quantitative analysis of the students' answers.

First, we computed what we labelled a "fear index", using questions about our students' prospective assessment of MT: we based the questions on the existing construct of computer anxiety and kept the associated negative to positive measures (as developed and validated by Heinssen et al., 1987) but we sought to produced appropriate wording using the fears expressed at the DGT. Overall, negative and positive scores reflect the students' choices on five-point Likert scales, pointing to the polarity of perceptions, while null scores are evidence that no opinion was expressed. Table 2 displays results sorted according to gender.

\begin{tabular}{|c|c|c|c|c|c|c|}
\hline $\begin{array}{c}\text { Student } \\
\text { code }\end{array}$ & Gender & $\begin{array}{c}\text { Fear index } 1 \\
\text { (before } \\
\text { class) }\end{array}$ & $\begin{array}{c}\text { Fear index } \\
\text { 2 (after } \\
\text { class) }\end{array}$ & Evolution & $\begin{array}{c}\text { Overall } \\
\text { perception }\end{array}$ & $\begin{array}{c}\text { Self- } \\
\text { efficacy }\end{array}$ \\
\hline 1 & F & -6 & -8 & - & - & 0 \\
\hline 2 & F & 0 & -1 & - & - & 4 \\
\hline 3 & F & -3 & -2 & + & - & 3 \\
\hline
\end{tabular}




\begin{tabular}{|c|c|c|c|c|c|c|}
\hline 5 & $F$ & 0 & 0 & None & Neutral & 4 \\
\hline 7 & $F$ & -2 & 3 & + & + & 4 \\
\hline 9 & $\mathrm{~F}$ & 0 & -2 & - & - & 1,5 \\
\hline 10 & $F$ & 2 & -2 & - & Neutral & 3 \\
\hline 11 & $F$ & -2 & -1 & + & - & 4 \\
\hline 12 & $F$ & -5 & 0 & + & - & 1 \\
\hline 14 & $F$ & 1 & 1 & None & + & 0 \\
\hline 17 & $F$ & 1 & -3 & - & - & 4 \\
\hline 18 & $F$ & 1 & 2 & + & + & 4 \\
\hline 4 & $M$ & 1 & -1 & - & Neutral & 1 \\
\hline 6 & $M$ & -2 & -2 & None & - & 5 \\
\hline 8 & $M$ & -1 & -1 & None & - & 3 \\
\hline 13 & $M$ & 0 & -1 & - & - & 4 \\
\hline 15 & $M$ & 1 & 2 & + & + & 1 \\
\hline 16 & $M$ & 2 & 3 & + & + & 5 \\
\hline 19 & $M$ & 3 & 3 & None & + & 4 \\
\hline
\end{tabular}

Table 2. Fear index and self-efficacy scores

Students' prospective assessments are very unstable: there are exactly as many negative evolutions of the fear index as there are positive ones, both within and across genders: both concern 7 students out of 19 (i.e. 36.8\%). Overall, however, there is an increase from negative perceptions initially expressed by a third of the group, to just over half of the group (52.6\%). The increase matches the perceptions of loss of control and authorship that students voiced in the focus group discussion, and it is in line with the current uncertainties about "what might or might not be the ultimate success of automated systems in dealing with problems or questions of translatability" (Cronin, 2013: 2; in Doherty and Kenny, 2014: 296). Besides, these results also show students moving away from neutral, unconfident assessment, thus suggesting they may have become more able to judge and decide for themselves. This is the kind of effect we were trying to achieve as a result of the above-described empowering strategies, but the fear index does not provide sufficient evidence for it. 
The construct of self-efficacy (i.e. "the belief that one has the capability to perform a particular behaviour", Compeau and Higgins, 1996: 189) was central to this survey: we used it to assess the students' confidence with MT after the class. Following Kenny and Doherty (2014: 304-305), we hypothesised that self-efficacy measures would give us a reliable indication of students' learning outcomes and performance with MT. The last column in table 2 displays scores, which were calculated as explained in appendix. Although we used both negative and positive figures to keep track of polarised answers, there are no negative scores and only two students produced null scores. Overall, we may interpret the scores as evidence for the success of the abovedescribed strategies, but variation as well as the presence of low scores also need to be accounted for.

We plotted the overall results on a line chart and noticed that some of our measures seemed to co-vary, so we computed Pearson's correlation coefficients between self-efficacy and our fear indices, and we found a significant positive relationship between fear index 2 and self-efficacy scores: $r(17)=.67, p<0.01$. Negative to low fear indices, as measured after the course, are thus related to lower selfefficacy scores, suggesting that students' anxiety should be addressed in order to enhance self-efficacy and improve learning outcomes. This finding, which is the main empirical result of the present study, will require further investigation and confirmation. There are two major caveats: first, because of the small size of our sample, we cannot infer much from the established correlation. Second, the observed variation across students is likely to be accounted for by a number of other factors that we did not control (e.g., self-concepts have not been fully assessed, and they would be one way of reaching beyond self-efficacy measures). The students voicing the most fear in our survey were also often heard throughout the course and in the focus group, as they reacted strongly against the very idea that MT might be of interest to the translator. This implies that the strategies we developed in this proposal failed to convince and help such students. More qualitative data (e.g. from individual interviews) would be particularly useful here.

More generally speaking, what is the possible impact of anxiety? Within the extended, third version of Venkatesh's technology acceptance model (Venkatesh and Bala, 2008) anxiety has indeed been shown to impact intention to use technology, while hands-on activities may reduce it. Thus, we interpret the mixed results presented here as an incentive to include more interactions with MT in the syllabus. In order to extend MT practice beyond the restricted number of hours allocated to the course, one possibility would be for students to use MT within at least one of their assignments, and ideally in the context of a professional project. In order to achieve this, however, we would need to make sure that the whole teaching team agrees. Our assessment of subjective norms suggests that a number of points still need to be addressed before we can move on.

\subsection{Subjective norms: students and teachers' perceptions}


Within technology acceptance models, subjective norm has been defined as "The degree to which an individual perceives that most people who are important to him think he should or should not use the System" (Venkatesh and Bala, 2008: 277), and has been shown to have an impact on actual use, through perceived usefulness. We assumed that as far as students were concerned, subjective norms may be of different kinds, including how they envisaged future employers' point of view, but for our present purposes we were primarily interested in their perception of teachers' opinions.

One month after the course, students anonymously answered the following closed question: "From the point of view of your teachers in this Master's degree, is it important that you should know how to use MT?" We also assessed teachers' opinion, and although our question primarily sought to determine how they envisioned further developments (i.e. "Are you in favour of using MT in translator training?"), it gave us a clear idea of their point of view on the importance of using MT in translator training. Strikingly enough, the proportion of positive and negative answers is relatively similar in students and teachers, as shown in figure 1 and 2 below. Out of 11 teachers, 8 were favourable and 3 were not, and out of 18 students, 12 thought it was important to their teachers that they should know how to use MT, and 6 thought it was not.

$$
\text { No }(27 \%)
$$

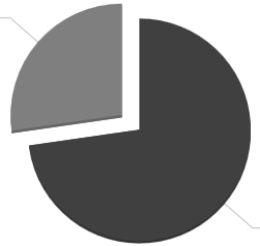

Yes $(73 \%)$

Figure 2. Teachers' point of view on using MT in translator training $(N=11)$.

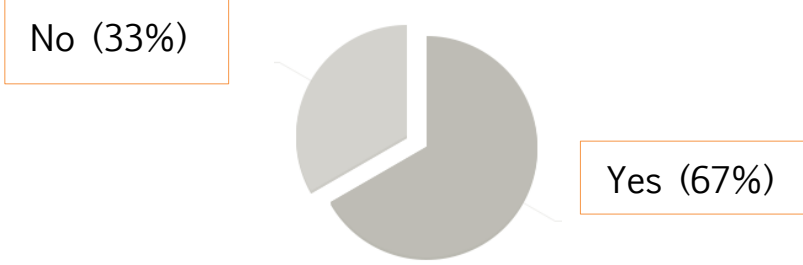

Figure 3. Students' assessment of teachers' point of view $(N=18)$.

The impact of a few teachers' negative views is thus clearly perceptible in students' assessments, and the above proportions show that 33\% of students had heard their teacher(s) utter negative remarks. These views need to be taken into account, especially since they are by and large based on genuine concern for the quality of the training students receive. Some teachers were indeed concerned that use of MT might affect terminological or document research competence. Further investigations are indeed needed to make sure that MT does not interfere with any other fundamental competences in translator training. 


\section{Conclusions}

The preliminary analysis presented here should be taken with caution: our results do not amount to an objective evaluation of our teaching strategies, nor do they correspond to a fully-fledged attempt to operationalise the existing constructs of computer anxiety and self-efficacy as levers to improve teaching and learning. However, the impact of fear that we evidenced needs to be addressed. We suggested that our failure to alleviate fears in at least some students could be linked with the course's limitations, which made it impossible to foster the development of professional expertise in the general use of MT. This is a major weakness of our proposal, which we are willing to address in the coming years.

Although it does seem necessary to extend the uses of MT in our curriculum, we are convinced that we cannot rely on practice alone, and that practice needs to be combined with the different steps taken in the present paper. It could be argued that preconceptions and fears of MT are comparable to what was observed with TMs two or three decades ago, and are likely to disappear as MT becomes more and more integrated in CAT tools. However, none of these changes are neutral and unprepared students could suffer from them, so that MT does and will need to be taught "in a way that empowers rather than instrumentalizes them in MT workflow" (Doherty et al. 2012).

\section{Acknowledgement}

This research is funded by the Pôle Grenoble Cognition as part of a multidisciplinary project on the uses and perceptions of machine translation (evaluerlata.hypotheses.org). We also wish to thank both anonymous reviewers for their in-depth comments, suggestions, and corrections, which have greatly improved the manuscript.

\section{Bibliography}

Bijker, W. E. (2009). "Social construction of technology", in A Companion to the Philosophy of Technology, Edited by J. K. B. Olsen, S. A. Pedersen and V. F. Hendricks, Blackwell Publishing Ltd. ISBN: 978-1-405-14601-2.

Cadwell, P., and S. Castilho, and S. O'Brien, and L. Mitchell (2016). "Human factors in machine translation and post-editing among institutional translators", Translation Spaces, 5, 222-243. DOI: 10.1075/ts.5.2.04cad

Compeau, D. R., and C. A. Higgins. (1995). "Computer Self-Efficacy: Development of a Measure and Initial Test." MIS Quarterly 19 (2): 189-211. DOI: 10.2307/249688.

Corness, P. (1985). "The ALPS computer-assisted translation system in an academic environment”, in: Picken, C. (ed.), Translating and the Computer 7. Aslib: London, 118-127. 
Directorate-General for Translation (2016). Annual Activity Report, available online at: https://ec.europa.eu/info/sites/info/files/file_import/aar-dgt-2016_en_0.pdf. Page consulted on July 10, 2017. Ref. Ares(2017)182661.

Doherty, S. and D. Kenny (2014). "The design and evaluation of a Statistical Machine Translation syllabus for translation students", The Interpreter and Translator Trainer, 8 (2): 295-315. DOI: 10.1080/1750399X.2014.937571

Doherty, S., and J. Moorkens (2013). "Investigating the Experience of Translation Technology Labs: Pedagogical Implications." Journal of Specialised Translation 19: 122-136. http://www.jostrans.org/issue19/art doherty.php.

Doherty, S., Kenny, D. and Way, A. (2012). "Taking Statistical Machine Translation to the Student Translator". AMTA, 10. DOI: 10.13140/2.1.2883.0727

Foti, M. (2015). "The Commission's Machine Translation Service". Presentation given at Translating Europe Regional Workshop on the opportunities and threats of machine translation for professional translators, Durham, 25 November 2015. http://www.ciol.org.uk/content/machine-translation-opportunities-and-threats

EMT Expert Group (2009). Competences for professional translators, experts in multilingual and multimedia communication. Brussels, European Commission. Available online at: https://ec.europa.eu/info/sites/info/files/emt_competences_translators_en.pdf. Page consulted on August 19, 2017.

Gaspari, F., Almaghout, H and S. Doherty (2015). "A survey of machine translation competences: insights for translation technology educators and practitioners", Perspectives: Studies in Translatology, 23 (3): 333-358. DOI: 10.1080/0907676X.2014.979842

Hearne, M. and A. Way (2011). "Statistical Machine Translation: A Guide for Linguists and Translators", Language and Linguistics Compass 5/5: 205-226. DOI: 10.1111/j.1749-818X.2011.00274.x

Heinssen, R. K., Glass, C. R., \& Knight, L. A. (1987). Assessing computer anxiety: Development and validation of the computer anxiety rating scale. Computers in Human Behavior, 3, 49-59.

Kenny, D. (2017). "Introduction". In Human Issues in Translation Technology, edited by Dorothy Kenny. Milton Park, Abingdon, Oxon: Routledge.

Kenny, D. (2016). "Translator vs Machine”, The Linguist, 55 (6):10-13.

Kenny, D. and S. Doherty (2014). "Statistical Machine Translation in the Translation Curriculum: Overcoming Obstacles and Empowering Translators", The Interpreter and Translator Trainer, 8 (2): 276-94. doi:10.1080/1750399X.2014.936112.

Kenny, D. and A. Way (2001). "Teaching machine translation and translation technology: a contrastive study" in: The MT Summit VIII Workshop on Teaching Translation 2001, 18-22 September 2001, Santiago de Compostela, Spain. http://doras.dcu.ie/15830/. Page consulted on September 07, 2017.

Koehn, P. (2016). MOSES. Statistical Machine Translation System User Manual and Code Guide. http://www.statmt.org/moses/manual/manual.pdf. Page consulted on August 30, 2017. 
Koskinen, K. (2008). Translating Institutions: An Ethnographic Study of EU Translation.

Saint Jerome Publishing.

Koskinen, K. and M. Ruokonen (2017). "Love Letters or Hate Mail? Translators' Affective Responses to Technology." In Human Issues in Translation Technology, edited by Dorothy Kenny. Milton Park, Abingdon, Oxon: Routledge.

Lavault-Olléon, E. and A. Carré (2012). « Traduction spécialisée: l'ergonomie cognitive au service de la formation», ASp, 62: 67-77. DOI:10.4000/asp.3117.

LeBlanc, M. (2017). "I can't get no satisfaction": Should we blame translation technologies or shifting business practices?' In Human Issues in Translation Technology, edited by Dorothy Kenny. Milton Park, Abingdon, Oxon: Routledge.

LeBlanc, M. (2014). « Traduction, bilinguisme et langue de travail : une étude de cas au sein de la fonction publique fédérale canadienne », Meta : journal des traducteurs / Meta: Translators' Journal, 59(3), 537-556. DOI: 10.7202/1028656ar

Niño, A. (2009). "Machine translation in foreign language learning: Language learners' and tutors' perceptions of its advantages and disadvantages", ReCALL, 21(2), 241258. DOI: $10.1017 / \mathrm{S} 0958344009000172$

Olohan, M. (2017). "Technology, translation and society. A constructivist, critical theory approach”. In Stefan Baumgarten and Jordi Cornellà-Detrell (eds.) Translation in times of technocapitalism, Target 29(2), 265-283. DOI:

10.1075/target.29.2.04oloPresas, M., Cid-Leal, P. and Torres-Hostench, O. (2016). "Machine translation implementation among language service providers in Spain: A mixed methods study", Journal of research design and statistics in linguistics and communication science, 3 (1): 126-144. DOI: 101558/jrds.30331

Venkatesh, V. and H. Bala (2008). "Technology Acceptance Model 3 and a Research Agenda on Interventions”, Decision sciences, 39 (2): 273-315. DOI: 10.1111/j.15405915.2008.00192.x

Way, A. and M. Hearne (2011). "On the Role of Translations in State-of-the-Art

Statistical Machine Translation", Language and Linguistics Compass 5/5: 227-248. DOI: 10.1111/j.1749-818x.2011.00275.x

\section{Appendix}

\subsection{Questions used in computing fear index:}

\begin{tabular}{|c|c|}
\hline $\begin{array}{c}\text { Question } \\
\text { English translation }\end{array}$ & $\begin{array}{c}\text { Possible answers (corresponding } \\
\text { scores) }\end{array}$ \\
\hline $\begin{array}{c}\text { Si vous utilisez la TA depuis plusieurs } \\
\text { années, même de façon ponctuelle, avez- } \\
\text { vous remarqué une évolution des } \\
\text { systèmes depuis vos premières utilisations } \\
\begin{array}{c}\text { ? } \\
\text { If you have been using MT for some time, }\end{array}\end{array}$ & No (0) - Yes (1) \\
\hline
\end{tabular}




\begin{tabular}{|c|c|}
\hline $\begin{array}{l}\text { even very occasionnally, have you noticed } \\
\text { an evolution of the technology since you } \\
\text { first used it? }\end{array}$ & \\
\hline $\begin{array}{c}\text { Pensez-vous que vous utiliserez dans } \\
\text { votre travail de traducteur un système de } \\
\text { traduction automatique ? } \\
\text { Do you think you will use MT as a } \\
\text { professional translator? }\end{array}$ & $\begin{array}{l}\text { absolutely not }(-2) \text {, rather not }(-1) \\
\text { don't know (0) maybe (1) I'm sure (2) }\end{array}$ \\
\hline $\begin{array}{c}\text { Si vous pensez utiliser la TA, quand } \\
\text { ''utiliserez-vous ? } \\
\text { If so, when will you use it? }\end{array}$ & $\begin{array}{l}\text { In a long time (-2), not too soon (-1) } \\
\text { don't know (0) quite soon (1) very } \\
\text { soon (2) }\end{array}$ \\
\hline $\begin{array}{l}\text { D'après vous, quel est l'impact de la TA } \\
\text { sur la pratique des traducteurs } \\
\text { professionnels? } \\
\text { According to you, what is the impact of } \\
\text { MT on professional translation practice? }\end{array}$ & $\begin{array}{l}\text { strong }(-2) \text {, rather strong }(-1) \text { neutral } \\
\text { (0) rather weak (1) weak (2) }\end{array}$ \\
\hline $\begin{array}{l}\text { Que pensez-vous que la TA constitue } \\
\text { pour le traducteur ? } \\
\text { What do you think MT represents for } \\
\text { translators? }\end{array}$ & $\begin{array}{l}\text { It is threatening }(-2) \text {, it is relatively } \\
\text { threatening }(-1) \text { don't know }(0) \text {, it is } \\
\text { relatively helpful (1), it is helful ( } 2 \text { ) }\end{array}$ \\
\hline
\end{tabular}

\subsection{Questions used in computing self-efficacy index}

\begin{tabular}{|c|c|}
\hline $\begin{array}{c}\text { Question } \\
\text { English translation }\end{array}$ & Possible answers (corresponding scores) \\
\hline $\begin{array}{c}\text { Pensez-vous pouvoir utiliser un système de TA } \\
\text { comme MT@EC dans un contexte professionnel à } \\
\text { l'avenir ? } \\
\text { Do you think you will be able to use an MT engine } \\
\text { such as MT@EC as a professional translator in the } \\
\text { future? }\end{array}$ & $\begin{array}{c}\text { Yes, absolutely (2) } \\
\text { Yes if someone else helps me get started (1) } \\
\text { Yes, if I could call someone for help if I got } \\
\text { stuck } \\
\text { (1, but only } 0.5 \text { if combined with previous } \\
\text { choice) } \\
\text { No (or very hardly) (-1) }\end{array}$ \\
\hline $\begin{array}{l}\text { Pensez-vous pouvoir utiliser un système de TA } \\
\text { intégré à un outil de TAO comme Trados Studio } \\
\text { dans un contexte professionnel à l'avenir ? } \\
\text { Do you think you will be able to use an MT engine } \\
\text { within a CAT tool such as Trados Studio as a } \\
\text { professional translator in the future? }\end{array}$ & $\begin{array}{c}\text { Yes, absolutely (2) } \\
\text { Yes if someone else helps me get started (1) } \\
\text { Yes, if I could call someone for help if I got } \\
\text { stuck } \\
\text { (1, but only } 0.5 \text { if combined with previous } \\
\text { choice) } \\
\text { No (or very hardly) (-1) }\end{array}$ \\
\hline
\end{tabular}


Pensez-vous que vous avez développé des compétences spécifiques en travaillant sur des sorties de TA et en faisant de la post-édition ? Yes (1) No (0) Do you think you have developed special skills linked with post-editing MT outputs?

Pensez-vous que vous seriez capable de juger si la TA peut ou non vous être utile pour une commande donnée?

Not at all $(-2)$

Not really $(-1)$

I don't know (0)

Yes maybe (1)

Do you think you would be able to judge whether MT could be useful or not for a given translation project?

\subsection{Teachers' questionnaire}

\begin{tabular}{|c|c|}
$\begin{array}{c}\text { Question } \\
\text { English translation }\end{array}$ & Possible answers \\
$\begin{array}{c}\text { Êtes-vous favorable à l'usage de la } \\
\text { traduction automatique dans la formation } \\
\text { du traducteur ? }\end{array}$ & Yes - No \\
Are you in favour of using MT within \\
translator training?
\end{tabular}




\begin{tabular}{|c|c|}
\hline & $\begin{array}{c}\text { Regularly } \\
\text { A quand remonte votre dernier usage de la } \\
\text { traduction automatique ? } \\
\text { When did you last use MT? }\end{array}$ \\
\hline $\begin{array}{c}\text { Quel(s) système(s) de traduction automatique avez- } \\
\text { vous déjà utilisé(s) au moins une fois ? } \\
\text { Which MT system(s) have you used at least once } \\
\text { already? }\end{array}$ & Any approximate date in figures. \\
\hline
\end{tabular}

